\title{
Texto: uma busca de definição
}

\author{
Nelyse A. Melro Salzedas \\ Universidade Estadual Paulista "Júlio de Mesquita Filho" (UNESP), Bauru, São Paulo, Brasil \\ nelysesalzedas@yahoo.com.br \\ Rivaldo Alfredo Paccola \\ Universidade Federal dos Vales do Jequitinhonha e Mucuri (UFVJM), \\ Diamantina, Minas Gerais, Brasil \\ rivapaccola@terra.com.br
}

DOI: http://dx.doi.org/10.21165/el.v46i3.1726

\begin{abstract}
Resumo
Nosso objetivo é discutir as várias definições de texto, sob o ponto de vista de diversos autores, já que não existe uma única. Seguindo a discussão de Enrique Bernárdez (1982), sob o ponto de vista da linguística textual, enumeraremos os teóricos que ora tendem para a pragmática (Schmidt, Hartmann, Galperin, Fonseca/Fonseca e Kozevniková); ora para o estruturalismo (Sakov); ora para o textema (Agrícola); ora aglutinando pontos linguísticos e pragmáticos, atividade linguística e sócio-comunicativa (Isenberg e Vichweger); ora para a situação sócio-comunicativa (Hausenblas); ora para o contexto situacional (Revzin). Considerando que o texto não é uma entidade imediatamente dada, para entendermos as condições de produção e recepção, fomos buscar uma experiência narrada na obra de Leal (1993), Fala maria favela, em que o contexto é determinante para sua realização. Para isso, Silva (2010) aponta o contexto como "conjunto de circunstâncias nas quais se insere um texto". Assim, concluímos que o texto é uma unidade linguística fundamentalmente comunicativa, produto da atividade verbal humana, que possui sempre um caráter social.
\end{abstract}

Palavras-chave: texto; contexto; definição de texto; teorias do texto.

\section{Text: a definition search}

\begin{abstract}
Our purpose is to discuss the various text definitions from the point of view of several authors, since there is not only one. Following the discussion of Enrique Bernardez (1982) from the point of view of text linguistics, we will enumerate the theorists who sometimes tend to pragmatic (Schmidt, Hartmann, Galperin, Fonseca/Fonseca and Kozevniková); sometimes to structuralism (Sakov); sometimes to textema (Agricola); sometimes coalescing linguistic and pragmatic points, linguistic activity and socio-communicative (Isenberg and Vichweger); sometimes to social communicative situation (Hausenblas); sometimes to the situational context (Revzin). Seeing the text is not an immediately given entity, to understand the conditions of production and reception, we were seeking a narrated experience in the work of Leal (1993) Fala maria favela, where the context is crucial for its realization. For this, Silva (2010) points out the context as a "set of circumstances in which you insert a text". Thus, we conclude that the text is a fundamentally communicative language unit, product of human verbal activity, which always has a social character.
\end{abstract}

Keywords: text; context; text definition; text theories. 


\title{
Introdução
}

A construção deste texto é o resultado de uma leitura crítica e dialógica entre os aportes teóricos e pragmáticos relativos à produção textual, que se consubstancia nos atos ilocutivos e perlocutivos vistos nos textos de Bernárdez (1982) e Leal (1993).

$\mathrm{O}$ ato de definir exige conhecimento de todos os termos que formalizam a definição, bem como precisão de objetivos, ponto de chegada. Definir "texto" implica definir linguagem e ambos os termos, ainda hoje, comportam uma estereotipia definidora. Por sua vez, a Linguística Textual pretende definir, delimitar, traçar a natureza e a funcionalidade do objeto texto.

Os estudiosos da matéria apresentam definições de texto dentro de um espectro bastante amplo. Carreter (1953, p. 391, tradução nossa), no Diccionario de Términos Filológicos seguindo a glossemática, define texto como "[...] todo conjunto analisável de signos. Portanto, são textos um fragmento de conversa, uma conversa inteira, um verso, um romance, a língua em sua totalidade, etc."1 .

No Dicionário Enciclopédico das Ciências da Linguagem, originariamente publicado em 1972 pela Éditions du Seuil, Todorov (1998, p. 267-268) entende que

\begin{abstract}
A noção de TEXTO não se situa no mesmo plano que a frase (ou de proposição, sintagma etc.); nesse sentido, o texto deve ser distinguido do PARÁGRAFO, unidade tipográfica de várias frases. O texto pode coincidir com uma frase como com um livro inteiro; ele se define por sua autonomia e por seu fechamento (mesmo que, num outro sentido, certos textos não sejam "fechados"); constitui um sistema que não se deve identificar com o sistema lingüístico mas pôr em relação com ele: relação ao mesmo tempo de contigüidade e de semelhança. Em termos hjelmslevianos, o texto é um sistema conotativo, pois é secundário relativamente a outro sistema de significação. Se se distinguem na frase verbal seus componentes fonológico, sintático e semântico, distinguir-se-ão igualmente no texto sem que entretanto esses componentes estejam situados no mesmo plano.
\end{abstract}

Para Dubois et al. (1978, p. 600), autores do Dicionário de Linguística, texto é:

1. [...] o conjunto de enunciados linguísticos submetidos à análise: portanto, o texto é uma mostra de compartimentos linguísticos que pode ser escrito ou falado [...]

2. L. Hjelmslev toma a palavra texto em seu sentido mais amplo e com ela designa qualquer enunciado, falado ou escrito, longo ou curto, antigo ou moderno. "Stop" é um texto tanto quanto O Canto de "Mio" Cid. Todo material linguístico estudado também forma um texto [...]. Constitui uma classe de gêneros analisáveis, por sua vez divisível em classes e, assim sucessivamente, até esgotar as possibilidades de divisão.

Já Rosental e Telenkova (1984, p. 483, tradução nossa), no Dictionary of Difficult Words in the Russian Language definem como: "produto da fala (enunciado) reproduzido por escrito"2.

Realmente, são bem diferenciadas essas definições, pois vão desde texto como qualquer produto da fala, de texto como córpus, a texto como produto escrito. Contudo,

\footnotetext{
1 “'...] todo conjunto analizable de signos. Son textos por tanto, un fragmento de conversación, una conversación entera, un verso, una novela, la lengua en su totalidade, etc.".

2 "speech product (enunciation) reproduced in writing".
} 
são unilaterais, excludentes, por isso restritivas, fugindo ao geral, ao amplo que caracteriza e fundamenta uma definição.

Em 1979, Janos S. Petöfi, em vários ensaios, tenta muitas definições, com perspectivas distintas. Outros autores adentrando pela pragmática, pela semântica fazem, igualmente, tentativas.

Bernárdez (1982) levanta, na linguística textual, algumas definições e, posteriormente, arrola-as em bloco para que se observem as perspectivas críticas e as diferenças específicas que algum definidor novo introduz na definição, transformando-a.

\section{Definições de texto na linguística textual}

Vejamos o elenco das onze definições arroladas por Bernárdez (1982, p. 79-81, grifo e tradução nossos):

1) Com texto pode ser designado tudo aquilo que é linguagem em forma comunicativa ou social, isto é, voltado ao interlocutor. ${ }^{3}$

Os elementos gordiais embasam-se na pragmática, enfatizando o interlocutor, a situação comunicativa e o social, estas últimas apoiadas no elemento principal: o interlocutor.

2) Poderíamos definir... o texto como o maior signo linguístico. (DRESSLER, 1973, p. 12 , tradução nossa). ${ }^{4}$

Esta definição contrasta com a de Hartman, inclinado para a Pragmática, uma vez que se posicione com o funcionalismo linguístico.

3) Texto é uma mensagem sob a forma de documento escrito, que consiste em uma série de enunciados unidos por liames de tipo léxico, gramatical e lógico. Tem caráter modal bem definido, orientação pragmática e uma adequada elaboração literária (GALPERIN, 1974, p. 7, tradução nossa). ${ }^{5}$

O traço marcante da lógica de Galperin é a inclusão do literário em oposição ao situado, do escrito em oposição ao falado; porém, conserva a postura pragmática ao inclinar-se para o locutor.

4) O texto é um sistema de enunciados que são entendidos como orações atualizadas. É o produto da atividade linguístico-espiritual do homem, aparece-nos como uma unidade especial de características semânticas e estruturais, e cumpre funções comunicativas nas

\footnotetext{
${ }^{3}$ Con texto puede designarse todo aquello que es lenguaje en forma comunicativa o social, es decir, referida al interlocutor (SCHMIDT, 1971, p. 39; citando a Hartmann).

${ }^{4}$ Podríamos definir... el texto como el mayor signo linguístico.

${ }^{5}$ Texto es un mensaje objetivado en forma de documento escrito, que consta de una serie de enunciados unidos mediante diferentes enlaces de tipo léxico, gramatical y lógico. Tiene carácter modal bien definido, orientación pragmática y una adecuada elaboración literaria.
} 
relações humanas, no domínio do material, da superestrutura e do espiritual (SAKOV, 1974, p. 13, tradução nossa). ${ }^{6}$

Sakov amalgama as várias correntes linguísticas: o estruturalismo, o idealismo linguístico, sem, contudo, ladear a pragmática ao incluir funcionalmente o homem, a situação comunicativa e a intersubjetividade locucional.

5) Entenderemos por texto... um complexo de signos linguísticos que mostram, pelo menos, as seguintes características: a sucessão de orações ordenada, integrada, finita, contínua, construída de acordo com as regras gramaticais, que o produtor (ou vários produtores) pretende que seja semanticamente fechada e que proporcionam o desenvolvimento linear da amplitude de um assunto a partir do seu núcleo temático (AGRICOLA, 1976, p. 13, tradução nossa). ${ }^{7}$

O enunciado definidor de Agrícola recai sobre o plano único do texto, sobre o textema; porém, torna dependente ao ético ao mencionar produtor e tema, formalizando, assim, os dois níveis do texto: êmico (relativo à estrutura interna, que caracteriza as unidades pela função que o sujeito lhes confere) e ético (exterior, sobre a linguagem, fornecendo à sua descrição apenas um ponto de partida), este último, produto da enunciação e, como tal, dotado de uma intencionalidade pragmática.

6) O texto é a forma primária de organização na qual se manifesta a linguagem humana. Quando ocorre a comunicação entre os seres humanos (falada/escrita) é na forma de textos. Uma vez que a comunicação humana é sempre uma ação social, o texto é ao mesmo tempo o aparelho por meio do qual a atividade linguística como uma atividade social-comunicativa é realizada. Um texto é, portanto, uma unidade comunicativa, ou seja, uma unidade em que a comunicação linguística é organizada. (ISENBERG, 1976, p. 54$)^{8}$

Isenberg (1977), em "Riflessioni sulla teoria del testo", entende que a comunicação oral/escrita visa a uma ação social. Aglutina pontos linguísticos e pragmáticos, atividade linguística e sócio-comunicativa.

7) Entenderemos por texto um signo linguístico, ou seja, um ordenamento de conteúdos conceituais como reflexos de fatos e fenômenos da realidade, e sequências de sons ou grafemas, estabelecido de acordo com um plano específico de atividade (regras de composição do texto ou regras de desenvolvimento de um tema) e realizado por meio de regras do sistema da língua. Todo o texto é, portanto, a nomeação de um determinado evento, processo, fato, circunstância ou situação da realidade, representa uma seqüência

\footnotetext{
${ }^{6}$ El texto es un sistema de enunciados que se entienden como oraciones actualizadas. Es producto de la actividad lingüístico-espiritual del hombre, se nos aparece como una unidad especial de características semánticas y estructurales, y cumple funciones comunicativas en las relaciones humanas, en el terreno de lo material, la superestructura, y lo espiritual.

${ }^{7}$ Entenderemos por texto... un complejo de signos lingüísticos que muestra al menos las características siguientes: sucesión de oraciones ordenada, integrada, finita, continua, construida de acuerdo con las reglas de la gramática, que el productor (o los varios productores) pretende que sea semánticamente cerrada, y que proporcionan el desarrollo lineal del desenvolvimiento de un tema a partir de su núcleo temático.

${ }^{8}$ El texto es la forma primaria de organización en la que se manifiesta el linguaje humano. Cuando se produce una comunicación entre seres humanos (hablada/escrita) es en forma de textos. Como la comunicación humana es siempre una acción social, el texto es al mismo tiempo la unidad por medio de la cual se realiza la actividad lingüística en tanto que actividad social-comunicativa. Un texto es, en consecuencia, una unidad comunicativa, o sea, una unidad en la que se organiza la comunicación linguística.
} 
de enunciados que refletem objetos e situações da realidade e as relações realmente existentes, ou potenciais, entre si. Os textos são o resultado da atividade linguística do ser humano. Mas, como a atividade linguística é uma atividade produtiva, criativa, com fins sociais..., todo texto desempenha, ao lado da função nominativa..., uma função comunicativa particular. Os aspectos nominativos e comunicativos estão intimamente relacionados no texto e se refletem especificamente na estrutura textual. (VICHWEGER, 1976, p. 197). ${ }^{9}$

Este trecho de Vichweger selecionado por Bernárdez condensa vários postulados teóricos que vão desde o estruturalismo à semiótica, da teoria do texto à pragmática. Ao admitir os aspectos do signo correlato aos referentes, como reflexos de feitos, fenômenos da realidade e ação social, circulam, num mesmo plano, o linguístico e o semiótico; ao admitir uma sucessão de enunciados, que reflete os objetos e as situações reais existentes e os aspectos comunicativos, encaminha-se para a pragmática, mais especialmente para 0 discurso.

8) Do ponto de vista da sua origem, o texto é produto e obra da atividade linguística "ativa" (bem como as atividades ligadas a ela) do ser humano, do ponto de vista do seu funcionamento, o texto é objeto da percepção e interpretação do receptor. O texto tem propriedades características para todos os produtos humanos com função social... (HAUSENBLAS, 1977, p. 147-148, tradução nossa). ${ }^{10}$

A marca do posicionamento de Hausenblas é a atividade produtiva que aparece na origem e no funcionamento do texto; introduz, ainda, o receptor como determinante da produção e da recepção e as possíveis variáveis advindas da função social. Mais uma vez, as relações interlocutivas, pressionadas pela intersubjetividade, pela situação sóciocomunicativa, não são ignoradas. A pragmática faz-se presente.

9) (Concebemos) o texto como um produto do ato de fala, como discurso em que uma mensagem é produzida e projeta uma prática significativa centrada no aqui e agora, por sua vez, configurada por um eu que lhe dá origem; emergirá como um vestígio material da dinâmica do conjunto de relações estabelecidas que se entrecruzam nos diferentes polos do ato verbal (FONSECA, F.; FONSECA, J., 1977, p. 113). ${ }^{11}$

\footnotetext{
${ }^{9}$ Entenderemos por texto un signo lingüístico, es decir, una ordenación de contenidos conceptuales como reflejos de hechos y fenómenos de la realidad, y sucesiones de sonidos o grafemas, realizada de acuerdo con un determinado plan de actividad (reglas de composición del texto o reglas de desarrollo de un tema) y realizada mediante las reglas del sistema de la lengua. Todo texto es, en consecuencia, la nominación de un determinado suceso, proceso, hecho, estado o situación de la realidad, representa una sucesión de enunciados que refleja los objetos y situaciones de la realidad y las relaciones realmente existentes, o potenciales, entre los mismos. Los textos son resultado de la actividad lingüística del ser humano. Pero como la actividad lingüística es una actividad productiva, creadora, con fines sociales..., todo texto cumple, conjuntamente con la función de nominación..., una determinada función comunicativa. Los aspectos nominativos y comunicativos están estrechamente relacionados en el texto y se reflejan de manera específica en la estructura textual.

${ }^{10}$ Desde el punto de vista de su origen, el texto es producto y obra de la actividad lingüística «activa» (así como de las actividades unidas a ella) del ser humano, desde el punto de vista de su funcionamiento el texto es objeto de la percepción e interpretación por el receptor. El texto posee propiedades características para todos los productos humanos con función social...

${ }^{11}$ (Concebimos) el texto como producto del acto del habla, como discurso en el que se produce un mensaje y se proyecta una práctica significante centrada en un aquí ahora configurado a su vez por un yo que le da
} 
Fonseca, F. e Fonseca, J. (1977) estão com Austin (1990) e Searle (1984); partindo do ato de fala, do contexto situacional, do eu emissor, circunscrito pela condição de produção, encaminham-se para a linha do discurso. Porém, admitem que se entrecruzam várias linguagens culturais, configuradas nos conjuntos de relações. Tal linha, também teorizada por Pechêux (1997), substitui a mensagem pela sequência verbal e a correlaciona ao locutor, ao receptor, à condição de produção, ao contexto situacional, à língua, estabelecendo o jogo linguístico. Mais uma vez a dominância é da pragmática linguística.

10) [...] o texto é um conjunto verbal funcional completo, um "ato de fala"... o texto é a fala-estruturada e, ao mesmo tempo, o conjunto comunicativo superior. (KOZEVNIKOVÁ, 1979 , p. 28,50 , tradução nossa). ${ }^{12}$

Esta definição conjuga-se às demais que perspectivam o texto funcionalmente, como ato de fala estruturado, como um polo comunicativo. Alinha-se à pragmática discursiva.

11) O texto é uma unidade linguística específica que não pode ser considerada apenas como um conjunto de proposições (A. A. Revzin, según REVZINA/SREJDER, 1979, p. 175 , tradução nossa). ${ }^{13}$

Revzin, em ensaio publicado na revista Poetics (1974), "On the continuous nature of the poetic semantics", contribui substancialmente com este estudo mostrando a influência da comunidade sócio-cultural, que é também comunidade política, na heterogeneidade da língua, mas também como ela equilibra a standard, assegurando a comunicação entre múltiplos grupos. $\mathrm{O}$ contexto situacional determina as relações interlocutivas, enfileirando mais esta definição na pragmática discursiva.

Como se pode analisar, se perpassarmos os olhos por estas definições, quase todas elas admitem que o texto seja formado por uma sucessão de frases e que possuem uma função comunicativa. Poucas se excluem deste campo teórico. Outras, além de ressaltarem a sequência verbal produzida pelo falante e dotada de intencionalidade comunicativa, especificam também uma função social. Enfim, grande parte delas sublinha a atividade - o caráter comunicativo; a intenção do falante, situação - o caráter pragmático; e ainda as normas regentes da estrutura textual. Tentando sintetizar as teorias e as definições, Bernárdez (1982, p. 85) propõe:

"Texto" é a unidade linguística comunicativa fundamental, produto da atividade verbal humana, que sempre tem caráter social; é caracterizado por seu fechamento semântico e comunicativo, bem como por sua coerência profunda e superficial, devido à intenção (comunicativa) do falante de criar um texto completo e estruturado por dois conjuntos de regras: as próprias do nível textual e as do sistema da língua. ${ }^{14}$

origen; surgirá como vestigio material de la dinámica del conjunto de relaciones que se establecen y entrecruzan entre los diferentes polos del acto verbal.

12 ... el texto es un conjunto verbal funcional completo, un «acto de habla»... el texto es el habla-estructurada y al mismo tiempo el conjunto comunicativo superior

${ }^{13}$ El texto es una unidad lingüística específica que no puede considerarse sólo como un conjunto de proposiciones.

14 «Texto» es la unidad lingüística comunicativa fundamental, producto de la actividad verbal humana, que posee siempre carácter social; está caracterizado por su cierre semántico y comunicativo, así como por su 
Esta tentativa, além de conter os diversos termos e propostas anteriores, introduz:

a) o núcleo linguístico-comunicativo básico como produto da atividade humana;

b) o caráter social da atividade humana;

c) o traço semântico-comunicativo do texto;

d) a estrutura superficial e profunda do texto, coerentes entre si;

e) o caráter social do texto;

f) a estrutura normativa decorrente do sistema linguístico e do nível textual.

Parece-nos que os elementos nucleares do texto aí estão: o caráter linguísticocomunicativo; o social; o situacional; o estrutural-normativo. Entretanto, um dos problemas mais agitados pelos teóricos do texto não é discutido: o modo como associa a comunicação linguística com a comunicação social. Isto vai envolver o ato de fala, a competência linguística, a competência textual e outras tantas competências e saberes, pois o texto, como unidade semântica e pragmática, não existe por si e nem em si mesmo. Não é autotélico. É um produto de diversas operações e atividades. Resulta-se do enunciar e do receber, efetiva-se em um processo de interação comunicativa, implicando fatores sociais, culturais, psicológicos etc., que envolvem tanto o emissor quanto o receptor. Por isso, a importância das competências através dos potenciais ilocutivos e perlocutivos, inerentes ao ato de fala.

Como se vê, o texto não é apenas uma sucessão casual e diferenciada de enunciados. É muito mais complexo. Não é à toa que teóricos, temerosos em defini-lo, circunscrevem-se às funções, à estrutura, à natureza e limitam-se a descrevê-lo, evidenciando a natureza linguística e sociológica do texto. Outros como Petöfi (1973), Kerbrat-Orecchioni (1980), Van Dijk (1981) abstiveram-se do rigor da definição:

"Eu uso o termo texto como uma noção básica indefinida com a interpretação implícita, de que todos "objetos" verbais (escritos ou falados) são considerados textos assim qualificados com base em alguma motivação intuitiva."15 (PETÖFI, 1973, p. 41, tradução nossa).

"Determinar quais são as propriedades dos textos representa a mesma tarefa da ciência do texto; portanto, não nos é possível para dar uma definição do conceito de texto." 16 (KERBRAT-ORECCHIONI, 1980, p. 254, tradução nossa).

"No entanto, parece necessário primeiro esclarecer o que queremos dizer com texto intuitivo."17 (VAN DIJK, 1981, p. 66, tradução nossa).

coherencia profunda y superficial, debida a la intención (comunicativa) del hablante de crear un texto íntegro, y a su estructuración mediante dos conjuntos de reglas: las propias del nivel textual y las del sistema de la lengua.

${ }^{15}$ I use the term text as an undefined basic notion with the implicit interpretation, that all (written or spoken) verbal "objects" are considered as texts qualifying for it on the basis of some intuitive motivation.

${ }^{16}$ Determiner ce que sont les propriétés des textes represente la tâche même de la Science du texte, il ne nous est donc pas possible donner une definition de la notion du text.

${ }^{17}$ Néanmoins, il nous semble nécessaire en premier lieu de préciser ce que nous entendons intuitivement par texte. 
Apesar da diversidade das correntes linguísticas e dos múltiplos aspectos das definições, em um ponto firmou-se a maioria: a função comunicativa. A concordância de postura crítica levar-nos-á à busca do elemento causa-efeito desta função.

Ora, tal função liga-se a um enunciado, realizado por sócios na transmissão, através de códigos convencionais, com intenção comunicativa. Joga, portanto, com os parceiros, com o código. Ao envolver os parceiros, atinge o social, pois envolve o código, o sistema. Ambos estão interligados, uma vez que os parceiros, ao manipularem o código, produzem a textualidade. Logo, a textualidade tem função normativa e aparece como estrutura necessária em todos os sistemas de comunicação. Assim sendo, o texto funciona como a realização linguística da textualidade. Produto do código, seria um conjunto de sinais comunicativos; produto dos parceiros, teria uma função sócio-comunicativa. É, pois, um produto simultâneo do linguístico e do social. Isto, como diz Schmidt (1978), exclui a sua concepção como estruturas puramente verbais e abordáveis exclusivamente por fatores linguísticos. "O texto não é uma entidade imediatamente dada ao pesquisador... O texto, independentemente de sua produção ou recepção (leitura), não existe." (SCHMIDT, 1978, p. 165).

As pesquisas de Schmidt (1978) e Isenberg (1977), que postulam uma teoria do texto de cunho sociopsicológico, fundamentados em grande parte na "teoria da atividade verbal" de psicólogos soviéticos como Luria, Leontév e Vygotsky, além de outros teóricos puros, pesquisadores e professores - de todos os níveis - que buscam respostas às suas indagações, diretrizes às suas pesquisas, com soluções metodológicas para 0 ensino, temos as consequências desse postulado: produção (função comunicativa e textualidade) e recepção (leitura e leitor) em duas etapas.

\section{Fala maria favela}

A partir de suas vivências, no ano de 1981, o professor da rede pública Antonio Leal relata, na obra Fala maria favela, a experiência em alfabetização desenvolvida na comunidade da Rocinha, Rio de Janeiro, com uma turma de 26 crianças entre nove e 11 anos "E/E, isto é, alunos com mais de três anos de escolaridade, que não aprenderam a ler e escrever" (LEAL, 1993, p. 7).

Leal (1993, p. 8) admite que lhe fascinava a "grande aventura de ser alfabetizador - descobridor de escritas, garimpeiro de palavras"; assim, propôs à diretora da escola assumir a regência de classe de alfabetização do referido grupo de crianças taxadas de "deficientes", "carentes", "marginais", "excepcionais" ou "especiais", "alunos que, diziase, não aprendiam nada e eram marginalizados dentro da própria escola".

O recém-iniciado no magistério, professor Leal (1993, p. 8), construiu sua prática, conforme narra, com "um grande mosaico, contendo experiências, descobertas e opiniões, salteados aqui e ali por pequenos casos \& coisas da vida pessoal". Assim, menciona a fórmula com a qual conseguiu seu objetivo a partir da criação do "alfabeto do Autor, constituído pelas próprias palavras carregadas de significado, que norteiam suas ideias palavras que alfabetizam, palavras alfabetizadoras.”.

Afastando-se dos métodos tradicionais de alfabetização, adotou uma forma criativa de despertar nessas crianças, com experiência de insucesso, o interesse pela aprendizagem, tendo como ponto de partida o jogo e a brincadeira. 
Favelado, analfabeto, homem que não se exprime, não se comunica livremente [...] Mergulhar no imaginário, no inconsciente, no cósmico, e vir à tona construindo linhas, desenhando favelas, vendo seu próprio perfil, alfabetizar-se criando alfabetos.

Alfabetizar não será iniciar alguém na manipulação de linguagens?

Alfabetizar pelo verbo, pela criação de palavras.

Alfabetizar pelo cinema, a 24 fotogramas por segundo.

Alfabetizar pela fotografia.

Alfabetizar pelo teatro. (LEAL, 1993, p. 9)

Utilizando-se da ludicidade, Leal (1993, p. 9-10) recorre à outra palavra que julga importante em seu alfabeto:

Experiência.

A experiência concreta não morre, não acaba, como se pensa. Nem como se costuma dizer: experimentou, acabou.

Entendo a experiência como vivência e como prática política.

Vivência porque não está em momento algum separada da vida, não pode ser compartimentada - faz parte de um todo, do conjunto orgânico dos comportamentos vividos.

A experiência não é profissional. É vida: vivida/ vívida/ viva. Experiência enquanto transformação.

O texto de Leal revela que as crianças não eram somente analfabetas (desconheciam as técnicas de utilização da escrita), mas também iletradas (eram incapazes de estabelecer o processo comunicativo), conforme leciona o professor Jean Foucambert, responsável pelo serviço de pesquisa no INRP (Instituto Nacional de Pesquisa Pedagógica) da França e um dos criadores da Associação Francesa pela Leitura, "Analfabetismo é o desconhecimento das técnicas de utilização da escrita; iletrismo é a falta de familiaridade com o mundo da escrita, uma exclusão em relação ao todo ou a parte desse modo de comunicação." (FOUCAMBERT, 1994, p. 18).

O objetivo de Leal (1993) é encaminhado no sentido de que

Para formar todos os alunos como praticantes da cultura escrita, é necessário reconceitualizar o objeto de ensino e construí-lo tomando como referência fundamental as práticas sociais de leitura e escrita. Por em cena uma versão escolar dessas práticas que mantenha certa fidelidade à versão social (não-escolar), requer que a escola funcione como uma microcomunidade de leitores e escritores. (LERNER, 2002, p. 17).

Assim, um ponto significativo para essa nossa discussão a respeito da definição e produção de texto foi a forma criativa com que Leal (1993) iniciou seu trabalho de alfabetização, quando essas crianças marginalizadas e iletradas começaram a perceber-se como "sujeitos", na atividade inicial. 
Uma das primeiras coisas que descobri é que, embora já estudassem juntos há vários anos, não sabiam os nomes uns dos outros. E isto era grave. No primeiro dia, me lembro, brincamos com o som dos nomes:

- De olhos fechados, vão dizendo o nome de vocês, primeiro baixinho, depois alto, alto, alto...

Alguns gritaram seus nomes, outros balbuciaram, outros emudeceram por completo, alguns nem fecharam os olhos.

- Agora, só o primeiro som do nome de vocês...

De novo alguns emudeceram: Alexandra, Adriana, Sônia, Ronaldo, José Edmílson... [...]

Me lembro de que nessa primeira aula fiz um trabalho gráfico com eles. Coloquei linhas no quadro, escrevendo em cada uma das extremidades os nomes dos alunos e da letra inicial de cada um. [...]

Pedi que prestassem bastante atenção aos seus nomes. Depois apaguei todas as letras deixando só os traços. E passei a perguntar:

-Quem é essa linha?

- Alexandre.

- E esta?

- Rivelino.

E assim por diante. A turma 111 estava toda ali, naquelas linhas que se cruzavam. E eles entenderam isso. (LEAL, 1993, p. 15-16).

O professor Leal produziu um texto com sua turma, a partir do elemento mínimo de significação, as letras iniciais dos seus nomes, mostrando como elas se entrecruzam, formando um tecido e "perdido neste tecido - nesta textura - o sujeito se desfaz nele, qual uma aranha que se dissolve ela mesma nas secreções construtivas de sua teia. Se gostássemos dos neologismos, poderíamos definir a teoria do texto como uma hifologia (hyphos é o tecido e a teia da aranha)." (BARTHES, 2002, p. 74).

$\mathrm{O}$ processo de alfabetização das crianças da turma $\mathrm{E} / \mathrm{E}$ prosseguia, quando o professor Leal (1993, p. 29) passou a utilizar um jogo gráfico abstrato de hexagramas e os alunos podiam "aumentar-lhes ou diminuir-lhes o tamanho, copiá-los ou criar novos. [...] Os hexagramas podem ser dispostos na folha como os meninos queiram.".

Aos poucos, trabalhando com o entrecruzamento de linhas, os alunos foram identificando as letras que se formavam nos vértices, as quais eram copiadas e entendidas. "Foi assim que meus alunos começaram a ler e que começamos a fazer ditado." (LEAL, 1993, p. 31).

Os jogos de linhas cruzadas passaram a ocupar parte da aula. "Propus, então, que os meninos descobrissem letras atrás dos traços secundários, e eles descobriram" (LEAL, 1993, p. 34).

Continua o relato da experiência: 
Depois escrevemos um hexagrama com TA e um com LA [...] Ficaram curiosos, até que um deles disse: LATA. [...] Lata não é uma palavra imediatamente realista. Ela é desenho de linhas retas com um referencial fantástico. [...] As combinações possíveis entre TA, LA e FA são mínimas no que diz respeito à criação de novas palavras. No que diz respeito a sons fundamentais, a sons fenomenais, geradores, a cadeia de significantes é enorme. [...] A LARA FALA. [...] E, finalmente: FALA MARIA FAVELA. (LEAL, 1993, p. 47$53)$.

E o autor-professor Leal (1993, p. 109-110) conclui que agiu com paixão no seu fazer docente. E o resultado?

[...] o resultado do meu trabalho não foi nenhum milagre e foi até modesto. Dos vinte e seis alunos que começaram na 111, nove não tiveram frequência e se evadiram, três não conseguiram avanços notáveis, três ficaram preparados para a alfabetização, só não conseguindo porque o "estalo" só deu no mês de novembro e onze alfabetizaram-se.

Faltavam três dias para o término das aulas [...] Nesse mesmo dia apresentei o último texto da cartilha, o último capítulo da história da Maria Favela deste ano.

\section{MARIA FAVELA FALA}

MARIA NÃO DIZIA NADA. VAVÁ ENSINOU ELA A LER E A FICAR PERGUNTANDO TUDO.

\section{AGORA MARIA ESTÁ MAIS FORTE.}

\section{HOJE É DOMINGO DE MANHÃ, ELA ESTÁ NA ASSOCIAÇÃO DE MORADORES DA ROCINHA. MARIA FAVELA FALA. VAVÁ FICA BRINCANDO DE VIVO- MORTO.}

O itinerário criado por Leal partiu de um texto situacional, ou seja, trazendo elementos do cotidiano das crianças, já que privilegiou o contexto, conforme o entendimento de Bernárdez (1982), pois é possível identificar os elementos textuais: um núcleo linguístico-comunicativo básico como produto da atividade humana; o caráter social da atividade humana; o traço semântico-comunicativo do texto; uma estrutura superficial e profunda do texto, coerentes entre si; o caráter social do texto; a estrutura normativa decorrente do sistema linguístico e do nível textual.

Assim, a função sócio-comunicativa do texto é dada pela relevância central do contexto histórico, que permite a sua explicação e interpretação, bem como os materiais ou os eventos históricos devem ser compreendidos no seu próprio contexto.

Com isso, o "texto não deve ser abordado como fenômeno meramente linguístico mas a partir de um modo de textualidade" (SCHMIDT, 1978, p. 163), já que por textualidade entende "uma dupla estrutura, isto é, uma estrutura a ser abordada tanto no aspecto linguístico como sob o aspecto social" (id., ib.).

Desse modo, Fala maria favela enfatiza as estruturas onde se organizam os constituintes de relevância sócio-comunicativa, uma vez que a produção e recepção de textos na Favela da Rocinha era praticamente irrealizável, pela barreira comunicativa, tanto que Leal (1993, p. 16) expõe sua concepção de texto: 
Resolvi trabalhar algumas conclusões básicas de texto:

1. Nosso alfabeto é abstrato, não tem nada de figurativo. A palavra mesa não tem nenhuma semelhança com a mesa; nem a palavra escola, com a escola.

2. Não se deve ligar a palavra ao desenho da coisa. Isso só confunde.

3. O alfabeto não é formal e separado do homem. Ele é uma manifestação profunda do ser e deve ser ritualizado.

No texto de Leal (1993), notamos uma busca de recepção-produção-recepção contextuada na pessoa mesmo e em suas circunstâncias. O princípio coletivo da experiência humana sobrepôs-se ao individual, causalizado pelo social. As reações coletivas, que aparecem nas histórias de vida dos habitantes da Rocinha, tematizam em torno da Brincadeira, Jogo, Família, Civismo, Clichê, Murais, Episódio cívico, Doméstica, Doença/fome/demência, Violência, Política. É a partir dessa tematização que a textualidade se evidencia e se marca como característica estrutural das atuações sóciocomunicativas através de seu sistema-código; e evidencia-se, igualmente, a natureza dupla do texto: a linguística e a social, pois o enunciado - realizado ou produzido através dos interlocutores pela língua-objeto, tem necessariamente intenção comunicativa e, como tal, obedece à modalidade textual.

\section{Texto e contexto}

Em magnífica obra editada em 2010, no capítulo Texto e contexto na história literária, Vítor Aguiar e Silva (2010, p. 234-235) refletem sobre as relações entre texto e contexto, especialmente interessante para esta discussão:

A palavra "contexto", proveniente do vocábulo latino contextus, significou primeiramente "conjunto das relações organizadas entre os elementos significativos do discurso". Nesta acepção, o contexto é o contexto verbal ou o contexto textual, estreitamente ligado aos conceitos de coesão e coerência textuais [...].

Já ao longo da segunda metade do século XIX, porém, a palavra "contexto" passou a ser utilizada sobretudo com o significado de "conjunto de circunstâncias nas quais se insere um texto". Nesta acepção mais alargada, "contexto" pode significar: a) conjunto de factores comunicativo-situacionais à luz dos quais devem ser interpretados os enunciados de um texto; b) o "contexto idiomático", para utilizar a terminologia de Eugenio Coseriu, ou seja, a própria língua como contexto, como fundo do saber a partir do qual e sobre o qual se constrói qualquer enunciado; c) em sentido mais especificamente literário, o interdiscurso, o intertexto e o arquitexto; d) finalmente, o contexto extraverbal, extratextual e extradiscursivo, isto é, o conjunto das circunstâncias sociais, políticas, religiosas, econômicas, culturais, etc., que condicionam ou orientam a produção e a interpretação de textos.

De acordo com as considerações de Silva (2010), entendemos que Leal (1993) conduziu seus alunos a serem leitores e produtores de texto, já que a ação pedagógica evidenciou a existência de:

a) conjunto de fatores comunicativo-situacionais: os alunos excluídos da favela da Rocinha, afinal, perceberam-se como sujeitos e portadores de um discurso 
que, antes, era silenciado por falta de oportunidade. Com os procedimentos didáticos utilizados, gradativamente, foram estabelecendo relações comunicativo-situacionais e alfabetizaram-se, isto é, puderam ler os textos e produzir os seus próprios;

b) contexto idiomático: a busca pela compreensão das palavras deu-se a partir da realidade, daquelas que faziam sentido para os alunos, que por eles eram utilizadas na oralidade, tais como LATA, FALA, FAVELA, etc.;

c) interdiscurso, o intertexto e o arquitexto: gradativamente, a compreensão e a produção de texto dos alunos foram-se ampliando;

d) extraverbal, extratextual e extradiscursivo: à medida que os alunos passaram a compreender o significado das palavras utilizadas por eles, pelos seus colegas, pelos moradores do bairro, sua tomada de consciência ganha foros de cidadania, pois Maria "ESTÁ NA ASSOCIAÇÃO DE MORADORES DA ROCINHA. MARIA FAVELA FALA.” (LEAL, 1993, p. 110).

\section{Considerações finais}

Podemos concluir que o texto deveria ser entendido com esse sentido construído coletivamente por um conjunto de indivíduos e, no caso da ação pedagógica do professor Antonio Leal, impulsionou a atividade de seus alunos, quer dizer, as reverberações de um afetaram o grupo a produzir seus próprios textos, com as dissonâncias peculiares da intersubjetividade dessa ação sócio-comunicativa.

Com isso, voltamos ao princípio de nossa exposição, pois o texto é uma unidade linguística fundamentalmente comunicativa, produto da atividade verbal humana, que possui sempre um caráter social.

\section{REFERÊNCIAS}

AUSTIN, J. L. Quando dizer é fazer. Tradução de Danilo Marcondes de Souza Filho. Porto Alegre: Artes Médica, 1990.

BARTHES, R. O prazer do texto. São Paulo: Perspectiva, 2002.

BERNÁRDEZ, E. Introducción a la lingüística del texto. Madrid: Espasa-Calpe, 1982.

CARRETER, F. L. Diccionario de Términos Filológicos. Madrid: Editorial Gredos, 1953.

DUBOIS, J. et al. Dicionário de Linguística. Tradução de Frederico Pessoa de Barros et al. São Paulo: Cultrix, 1978.

FONSECA, F. I.; FONSECA, J. Pragmática, linguística e ensino de português. Coimbra, Almedina, 1977.

FOUCAMBERT, J. A leitura em questão. Porto Alegre: Artes Médicas, 1994.

ISENBERG, H. Riflessioni sulla teoria del testo. In: CONTE, M.-E. La lingüística testuale. Milão: Feltrinelli Economica, 1977. p. 66-85. 
KERBRAT-ORECCHIONI, C. L'énonciation de la subjectivité dans le langage. Paris: Armand Colin, 1980.

LEAL, A. Fala maria favela: uma experiência criativa de alfabetização. 12. ed. São Paulo: Ática, 1993.

LERNER, D. Ler e escrever na escola: o real, o possível e o necessário. Porto Alegre: Artmed, 2002.

PECHÊUX, M. O discurso: estrutura ou acontecimento. Tradução de Eni Pulcinelli Orlandi. Campinas: Pontes, 1997.

PETÖFI, J. S. Text-grammars, text-theory and the theory of literature. Poetics: Journal of Empirical Research on Literature, the Media and the Arts, v. 2, Issue 3, p. 36-76, 1973.

REVZIN, I. I. On the continuous nature of the poetic semantics. Poetics: Journal of Empirical Research on Literature, the Media and the Arts, v. 3, Issue 2, p. 21-26, 1974.

ROSENTAL, D. E.; TELENKOVA, M. A. Slovar Trudnostei Russkogo Yazika (Dictionary of Difficult Words in the Russian Language). Moskow: Prosveshenie, 1984.

SCHMIDT, S. J. Linguística e teoria do texto. São Paulo: Pioneira, 1978.

SEARLE, J. R. Os actos de fala. Coimbra: Almedina, 1984.

SILVA, V. M. de A. e. As humanidades, os estudos culturais, o ensino da literatura e a política da língua portuguesa. Coimbra: Almedina, 2010.

TODOROV, T. O texto. In: DUCROT, O.; TODOROV, T. Dicionário enciclopédico das ciências da linguagem. São Paulo: Perspectiva, 1998, p. 267-271.

VAN DIJK, T. A. Théorie de la littérature. Paris: Picard, 1981.

Recebido em: 24/09/2016

Aprovado em: 29/11/2016 